\title{
Persistence of epiphytic lichens along a tephra-depth gradient produced by the 2011Puyehue-Cordón Caulle eruption in Parque Nacional Puyehue, Chile
}

\author{
Persistencia de líquenes epifitos lo largo de un gradiente de profundidad de tefra producida por la \\ erupción de 2011 del complejo Puyehue-Cordón Caulle en el Parque Nacional Puyehue, Chile
}

\author{
Peter R Nelson ${ }^{\text {a*, Tim B Wheeler }}{ }^{\text {b }}$ \\ *Corresponding Author: a University of Maine-Fort Kent, Arts and Sciences Division, \\ Fort Kent, USA, phone: +1-541-231-5584, peter.nelson@maine.edu \\ ${ }^{\mathrm{b}}$ Arlee, MT, USA.
}

SUMMARY

Lichens, symbioses between fungi and algae or cyanobacteria, are diverse and abundant in humid temperate forests in mountain ranges such as the Andes. They are also sensitive to changes in atmospheric conditions. We suspected lichens would show die back as a result of tephra fall from the 2011 Puyehue-Cordón Caulle volcanic eruption. We measured macrolichen community composition six months after initiation of the Caulle eruption at four sites along a tephra depth gradient from 10 to $50 \mathrm{~cm}$. We also monitored the lichen community on permanent tree-bole quadrats over the next three years. We found 81 macrolichens species on seven plots at four sites across the tephra depth gradient. Plot species richness ranged between 23 and 34 lichen taxa. Nearly three years after the eruption, lichens in quadrats on tree boles showed no obvious trend of mortality in response to depth of tephra deposition. We concluded that lichen communities, despite being sensitive to atmospheric conditions, were able to survive the disturbance of up to $50 \mathrm{~cm}$ of tephra deposition three years after the eruption in part because of their position on the vertical sides of tree boles, which prevented abrasive impact and smothering by tephra deposition.

Key words: montane forest, repeat photography, vegetation, volcanic disturbance

\section{RESUMEN}

Los líquenes, una simbiosis entre un hongo y un alga o cianobacteria, son muy diversos y abundantes en bosques templados húmedos en sistemas cordilleranos como lo es la Cordillera de Los Andes. Asimismo, son altamente sensibles a los cambios en las condiciones atmosféricas. Producto de la erupción del volcán Puyehue-Cordón Caulle del año 2011, se predijo su potencial disminución y desaparición. Para evaluar esta condición, se midió la comunidad de macrolíquenes seis meses después del inicio de la erupción del volcán Puyehue-Cordón Caulle en cuatro sitios con diferente grado de depósito de material volcánico, con profundidades de entre 10 y $50 \mathrm{~cm}$. También se monitorearon las comunidades liquénicas en cuatro cuadrantes permanentes en un lapso de tres años. Fueron encontradas 81 especies de macrolíquenes en siete parcelas en cuatro sitios a lo largo del gradiente de acumulación de material piroclástico o tefra. La riqueza de las parcelas varió entre 23 y 34 especies. Luego de casi tres años después de la erupción, la presencia de líquenes en cuadrantes sobre troncos de árboles no mostró tendencia alguna hacia la mortalidad en respuesta a diferentes profundidades de depósito de material piroclástico. Se concluyó que las comunidades liquénicas, a pesar de ser sensibles a las condiciones atmosféricas, fueron capaces de sobrevivir a la acumulación de hasta $50 \mathrm{~cm}$ de depósito de material piroclástico tres años después de la erupción, en parte dada la posición vertical de los troncos, que previno el impacto abrasivo y cobertura del material piroclástico.

Palabras clave: bosque montano, disturbio volcánico, repetir fotografía, vegetación.

\section{INTRODUCTION}

Biotic responses to volcanic eruptions vary widely depending on the organism and nature of the volcanic disturbance. Understanding biotic factors involved in ecosystem responses to disturbance can help us better gauge future effects of volcanism on ecosystems, interpret biological legacies and prepare for or mitigate problems for human activities after eruptions. Although many studies document vegetation responses to volcanic eruptions (Veblen et al. 1977,
Grishin et al. 1996, Antos and Zobel 2005) relatively few have examined lichens. Lichens, symbioses between fungi, algae and/or cyanobacteria, are ubiquitous in temperate rain forest ecosystems along the Pacific rim, including southern Chile (Galloway 1988, 1992). In temperate forests, lichens can contribute large amounts of nitrogen (Kurina and Vitousek 1999), significantly add to the terrestrial biodiversity (Galloway 1995) and stabilize soil (Jackson and Keller 1970). Lichens are also highly sensitive to atmospheric conditions and have been widely used in air quality monitoring 
(Conti and Cecchetti 2001). By virtue of their sensitivity, they may also provide a uniquely sensitive measure of the ecological impacts of atmospheric chemical changes caused by a volcanic eruption (Davies and Notcutt 1988).

Most studies of volcanic disturbances that included lichens focused on establishment on lava flows (Skottsberg 1941, Jackson 1971, Bjarnason 1991, Kitayama et al. 1995, Sipman and Raus 1995). The handful of studies that examined other types of eruption processes, such as tephra fall (Grishin et al. 1996), pyroclastic flows or lahars (Nelson et al. In Press), occurred more than 30 years after the eruption. The eruption of the Puyehue-Cordón Caulle complex in south-central Chile, which began June 4, 2011, provided an opportunity to study lichen responses within months after an eruption. The eruption also created a gradient of tephra depth along which lichen response could be observed. Our general goals are to observe lichen community composition along a tephra depth gradient and monitor lichen community changes across several years in the most impacted areas accessible around Volcán Puyehue. We expected that lichens would likely perish soon after the eruption, due to their sensitivity to physical abrasion from tephra, heat and volcanic chemical emissions.

\section{METHODS}

Study area. See Swanson et al. (2016) for description of sampling area, situated on the border between Chile and Argentina southeast of Volcán Puyehue along Ruta 215 in an area between Chilean and Argentinean customs stations.

Plot selection. Access to the eruption zone near Volcán Puyehue was constrained to areas easily accessible on foot from Ruta 215. We installed plots in January 2012 positioned along the tephra depth gradient at 10,25, 35 and $50 \mathrm{~cm}$ tephra depths in patches of native forest with no evidence of human disturbance and located on gentle slopes hence the tephra remained in place. The forest type on plots varied along the tephra depth gradient. Plots at $10 \mathrm{~cm}$ of tephra depth were dominated by Laureliopsis philippia$n a$ (Looser) Schodde. with a few, large Nothofagus dombeyi (Mirb.) Oerst. and significant Chusquea culeou Desv. understory cover. Forests in plots at $20 \mathrm{~cm}$ of tephra depth were dominated by a mixed-size stand of $N$. dombeyi with a few Nothofagus pumilio (Poepp. et Endl.) Krasser and some Drimys andina (Reiche) R.A. Rodr. et. Quez. protruding from the tephra. At $35 \mathrm{~cm}$ of tephra depth, our plots were dominated by a relatively dense, even-sized cohort of $N$. pumilio with a few, larger $N$. dombeyi and some $D$. andina understory. The forests at $50 \mathrm{~cm}$ of tephra depth were composed by a mixture of $N$. dombeyi and $N$. pumilio and some $D$. andina understory. See Swanson et al. (2016) for more details on forest structure on the plots.

At each tephra depth station, two circular plots $34.7 \mathrm{~m}$ in radius were positioned at both ends of a $100 \mathrm{~m}$ transect used by Swanson et al. (2016). On each plot, two methods were used to measure the lichen community; 1) we estimated the abundance of each macrolichen species on all substrates by searching the entire plot and; 2) measured the abundance of lichens through time (without identifying lichen species) using repeated photography of $0.2 \mathrm{~m}^{2}$ quadrats installed on selected tree boles.

Plot sampling. On each plot, one of the two authors surveyed the lichen community on all available substrates, which involved searching for macro-lichen species (larger species, excluding crustose species requiring microscopy for identification, hereafter referred to as "lichen"). Vouchers of species not confidently identifiable in the field were collected for identification in the lab. Each lichen species was assigned one of four abundance classes: $1=$ $1-3$ thalli, $2=4-10$ thalli, $3=>10$ thalli, $4=$ more than half available substrate occupied by the species. A thallus is an individual lichen. Available substrate means boles, branches and twigs of trees and shrubs for epiphytic species and the ground surface and thin soil over rock for terricolous species. Each plot was searched for a minimum of 30 min and maximum of $2 \mathrm{~h}$. Searching ceased when $15 \mathrm{~min}$ elapsed without finding a new species.

Tree quadrats. One tree on each plot (two trees per transect) was opportunistically selected as representative of the lichen community. The tree species, circumference at breast height (1.37 m above ground) and whether it was alive or dead were recorded. Four stainless steel rivets were driven into the tree demarcating a permanent, rectangular quadrat $0.2 \mathrm{~m}^{2}$ in area $\left(75 \mathrm{~cm} \times 26.666 \mathrm{~cm}=2,000 \mathrm{~cm}^{2}\right)$ with bottom of each quadrat $1 \mathrm{~m}$ above ground. We selected this size of quadrat to fit on a range of tree diameters while also remaining relatively flat for photography, capturing a large enough area of the tree bole but not being too large to make examination and photographing the quadrat physically cumbersome. In 2012, we took high-resolution digital photographs of each quadrat, with subsequent photographs taken January 2013 and December 2013. We used "2014" to designate the austral summer of 2013-2014. Quadrat lichen cover was estimated by superimposing a grid of 100 points on each image in Adobe Photoshop and counting the number of points intersecting live lichens.

\section{RESULTS}

A wide range of lichen species survived the initial eruption. Most lichens were encountered on boles, branches or litter fall. Very few lichens were observed growing on the ground and all those found on the tephra surface were litter fall from the canopy, not surviving terrestrial lichens.

Eighty-one lichen species were found on the plots. Lichen species richness ranged from 23 to 34 species on a plot (table 1).

Initial lichen cover within the $0.2 \mathrm{~m}^{2}$ tree quadrats ranged from nine to $66 \%$ cover. Lichen cover on the tree qua- 


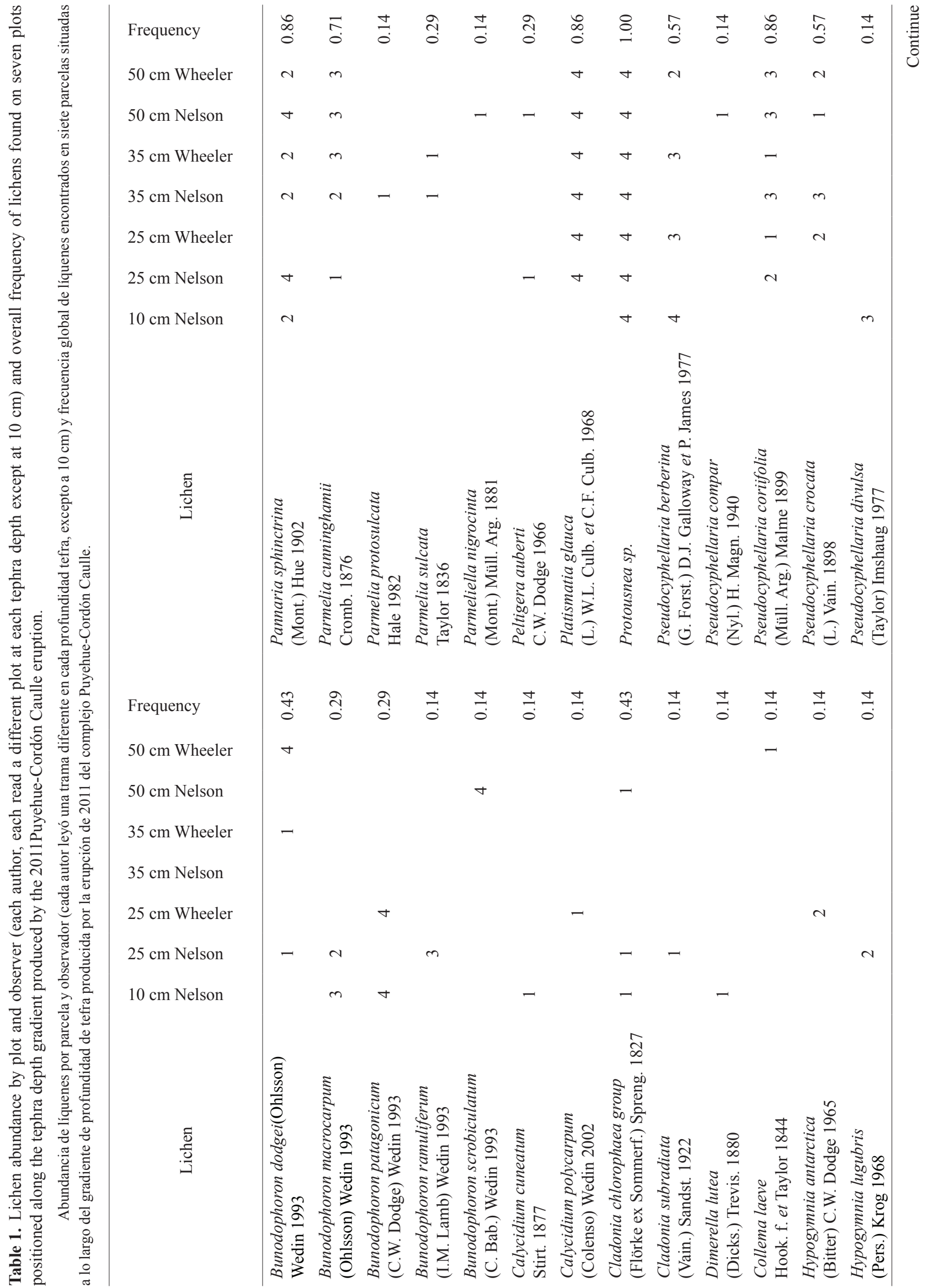




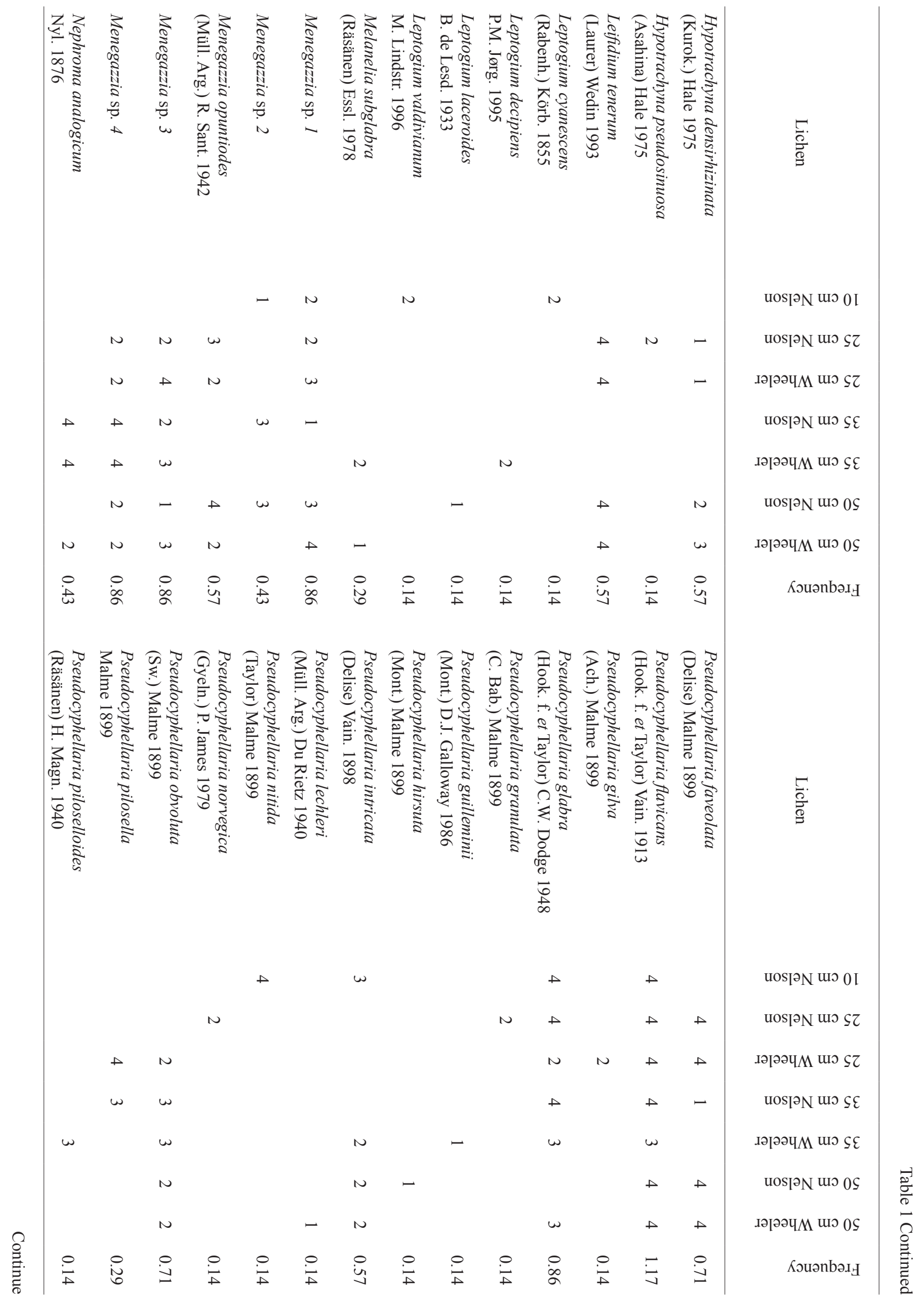




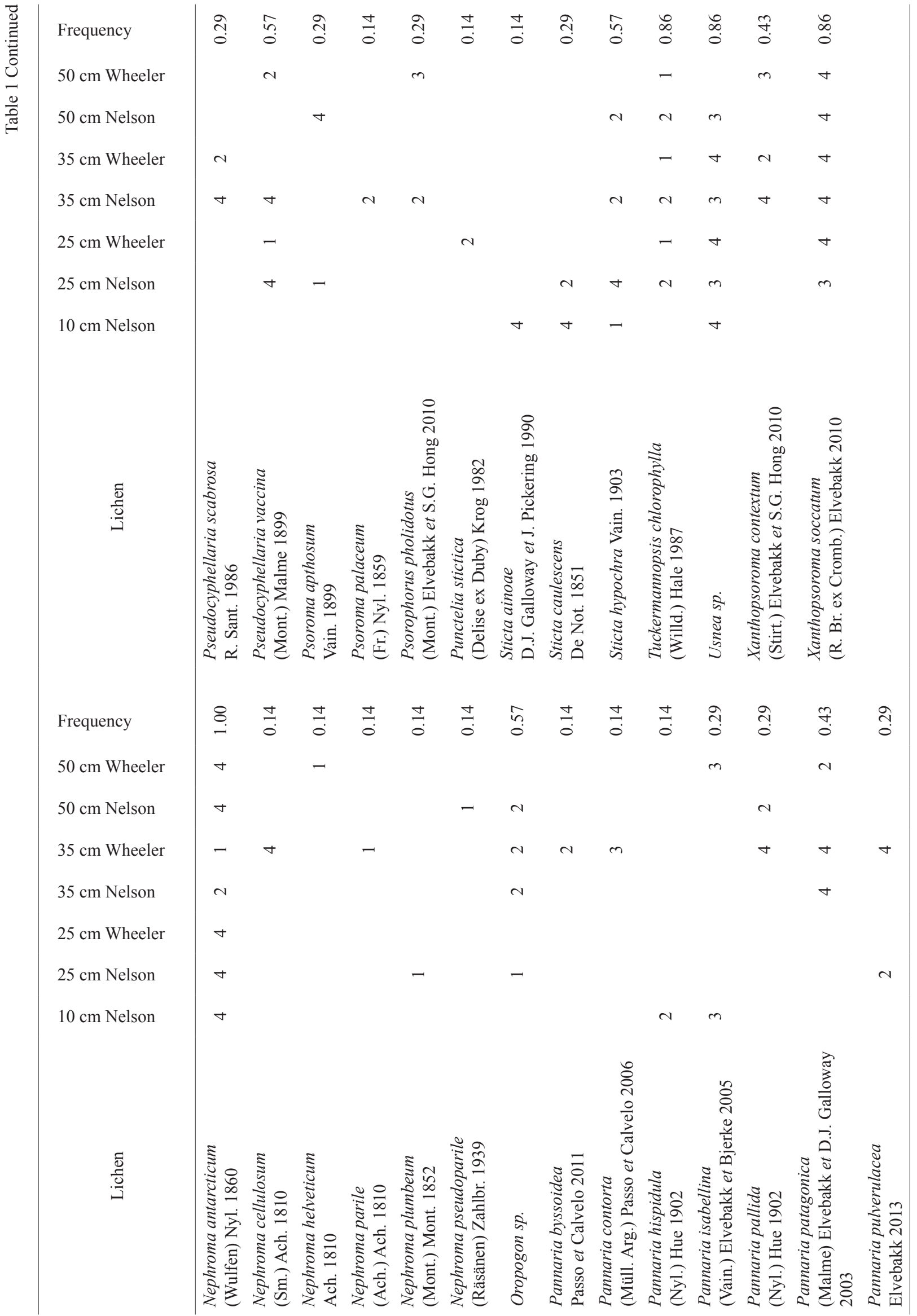


drats heterogeneously changed between 2012 and 2014 with respect to tephra depth. For example, at $35 \mathrm{~cm}$ in the tephra depth site, lichen cover increased on one tree and decreased on another tree at the same site (table 2). Even three years after the eruption, images of the lichens in the tree quadrats appeared remarkably similar to the images taken six months after the eruption began (figure 1). We could easily distinguish the same, individual lichen thalli with more or less the same extent alive for most thalli in most of the tree quadrats three years after the eruption.

\section{DISCUSSION}

Epiphytic lichens are generally poorly adapted to physical disturbance, at least in the short term (Johansson 2008). They are also sensitive to both low $\mathrm{pH}$ precipitation and high concentrations of sulphur dioxide (Hawksworth and Rose 1970) or hydrogen fluoride (Nash 1971), all of which are atmospheric chemical changes potentially produced by volcanic eruptions. We expected lichen species richness and abundance would decrease in response to a combination of physical or chemical disturbance originating from Puyehue-Cordón Caulle eruption. We specifically expected tephra fall to either smother or abrade lichens

Table 2. Count of points (out of 100) in each tree quadrat covered by lichen from the three years since the 2011 Puyehue-Cordón Caulle eruption. Site is the depth of tephra, tree is the species (coihue $=$ Nothofagus dombeyi (Mirb.) Blume and lenga $=$ N. pumilio (Poepp. et Endl.) Krasser), status is either alive or dead and size is circumference at breast height $(1.3 \mathrm{~m})$. Change is the magnitude and direction of change of percent lichen cover between 2012 and 2014 .

Cantidad de puntos (sobre 100) en cada cuadrante de árbol cubierto por líquenes en los tres años desde la erupción de 2011 del complejo Puyehue-Cordón Caulle. Sitio es la profundidad de tefra, árbol es la especie (coigue $=$ Nothofagus dombeyi $($ Mirb.) Blume y lenga $=$ $N$. pumilio (Poepp. et Endl.) Krasser), el estado es vivo o muerto y el tamaño es el perímetro a la altura del pecho $(1,3 \mathrm{~m})$. El cambio es la magnitud y la dirección del cambio de la cubierta de líquenes en porcentaje entre 2012 y 2014.

\begin{tabular}{lcccc}
\hline Site/Tree/Status/Size & 2012 & 2013 & 2014 & Change \\
\hline $10 \mathrm{~cm}$, coihue, dead, $360 \mathrm{~cm}$ & 57 & 55 & 41 & -16 \\
$10 \mathrm{~cm}$, coihue, dead, $720 \mathrm{~cm}$ & 29 & 36 & 35 & +6 \\
$25 \mathrm{~cm}$, coihue, dead, $148 \mathrm{~cm}$ & 31 & 39 & 27 & -4 \\
$25 \mathrm{~cm}$, coihue, dead, $210 \mathrm{~cm}$ & 9 & 16 & 7 & -2 \\
$35 \mathrm{~cm}$, lenga, alive, $134 \mathrm{~cm}$ & 66 & 62 & 56 & -10 \\
$35 \mathrm{~cm}$, lenga, alive, $195 \mathrm{~cm}$ & 18 & 31 & 28 & +10 \\
$50 \mathrm{~cm}$, coihue, dead, $269 \mathrm{~cm}$ & 49 & 43 & 35 & -14 \\
$50 \mathrm{~cm}$, lenga, alive, $149 \mathrm{~cm}$ & 22 & 32 & 16 & -6 \\
\hline
\end{tabular}

and anticipated changes in atmospheric chemistry caused by the eruption could cause lichen damage or mortality. Both of these expectations were proven to be unsupported. Pre-eruption forest conditions differed among plots, which also contributed to the observed variation in lichen communities, independent from the volcanic disturbance. Nonetheless, our results here support the simple, yet surprising, conclusion that many epiphytic lichens were able to persist after a range of tephra deposition depths.

Previous studies on lichen responses to volcanism, all of which occurred decades after the eruptions, found lichen species richness and cover can be quite high in disturbed areas. However, most previous studies occurred in subalpine or alpine habitats where terrestrial lichens are more common even before the eruption. In contrast, our field experience in south central Chilean forest prior to the eruption suggests terrestrial lichens are relatively low in abundance and diversity compared to the epiphytic lichen community because of the small amount of habitat suitable for ground dwelling lichens, such as rock outcrops or thin, gravelly soils and very low light conditions that favor bryophytes. Coarse woody debris, however, is common on the ground in these forests and is often colonized by lichens predominantly found on wood, such as some Cladonia sp. We found only two of the 13 Cladonia species reported from nearby Parque Nacional Vicente Pérez Rosales (Rédon 1974) suggesting these lichens may have been buried by tephra or conditions were not suitable prior to the eruption, such as extremely low light conditions or competition from bryophytes.

Grishin et al. (1996) studied vegetation response, including lichens, along a tephra depth gradient 89 years after the Ksudach volcano erupted on the Kamchatka peninsula, Russia, in 1907. However, they sampled only ground-dwelling lichens, excluding epiphytes from their sampling. They found an increase in ground-dwelling lichen diversity with increasing tephra depth. The species richness pattern at Ksudach suggests lichens escaped competitive pressure by colonizing harsh physical environments devoid of vascular vegetation where deep tephra suppressed vascular plant growth. This supports the established theory that lichens are stress tolerant and poor competitors (Grime 1977). Another study sampled all lichens, including epiphytes, in different disturbance zones 32 years after Mount St. Helens erupted in 1980 (Nelson et al. In Press). They found overall lichen diversity was higher on the massive landslide deposit, where lichens had a wide variety of substrates, including two species of trees, shrubs, rocks and soil, to grow upon and yet a low density of plants competing for resources. In the relict forest patches subjected to tephra fall near Mount St. Helens, Nelson et al. (In Press) found that many lichens common in old-growth forest canopies (measured via litterfall and fallen branches) and boles apparently survived the eruption. However, it is not clear whether all or some of the lichen species they observed in the relict forest actually persisted 


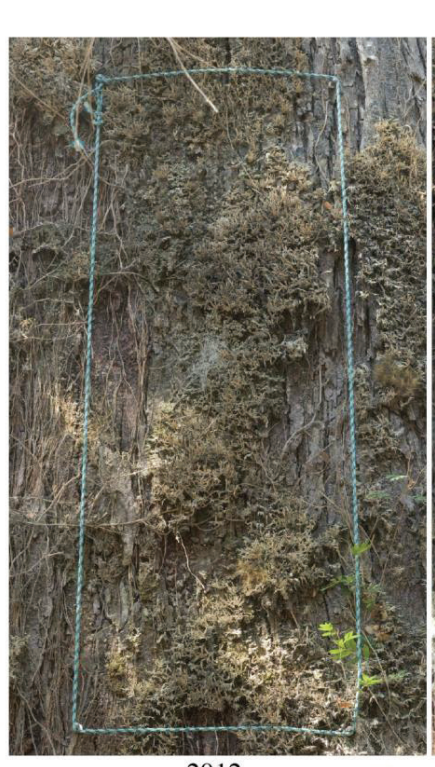

2012

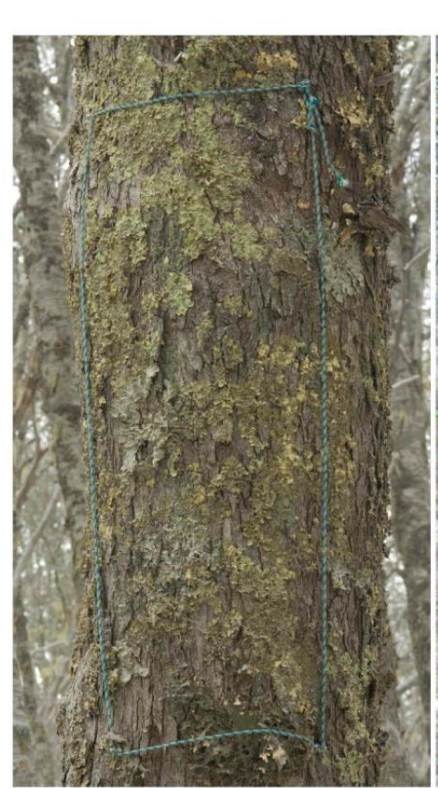

2012
TDN-10 Coigue Dead 115

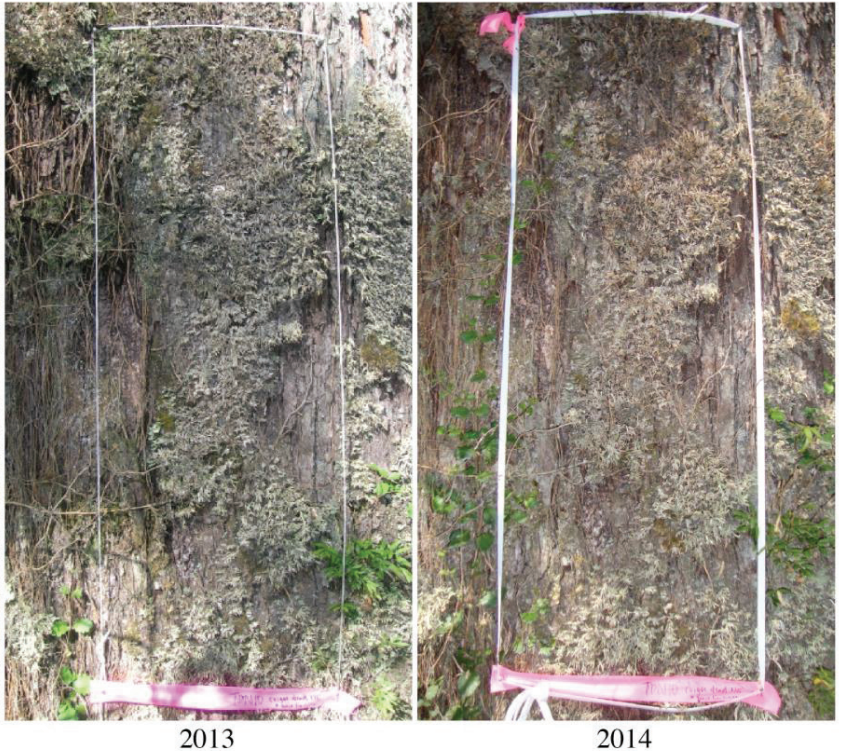

TDN-35 Lenga Alive 134

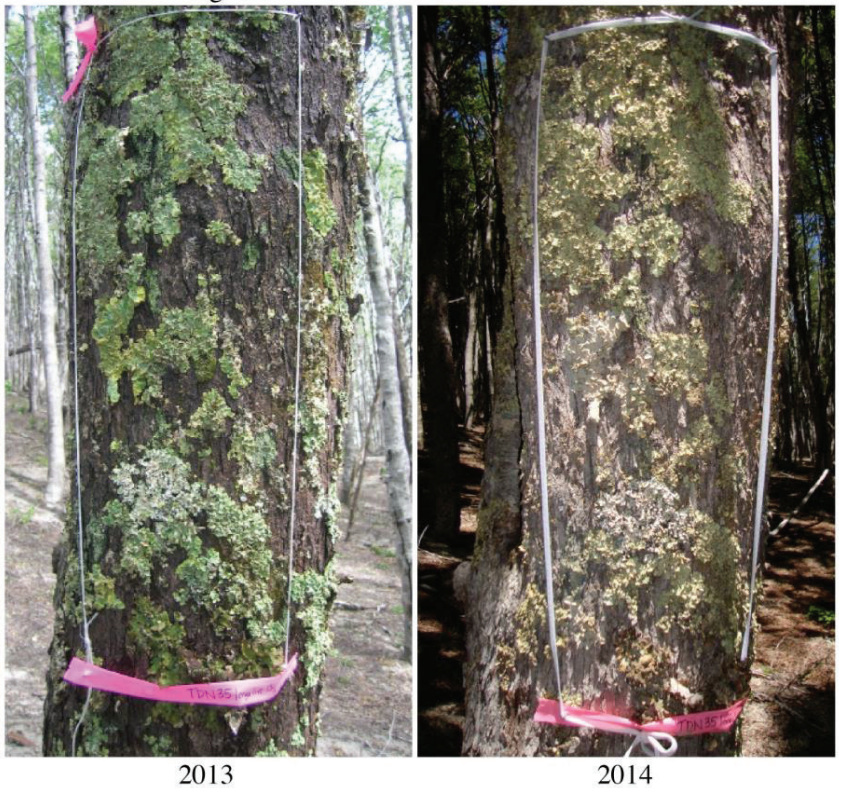

Figure 1. Photographs of tree quadrats at $10 \mathrm{~cm}$ and $35 \mathrm{~cm}$ tephra depths 6 months, 1.5 and 2.5 years after the June 4, 2011 PuyehueCordón Caulle eruption.

Fotografías de los cuadrantes de árboles en $10 \mathrm{~cm}$ y $35 \mathrm{~cm}$ de profundidad de tefra seis meses, 1,5 y 2,5 años después de la erupción del 04 de junio de 2011 del complejo Puyehue-Cordón Caulle.

or re-colonized in the 32 years between the eruption and sampling. Several of the species they found are thought to be very dispersal limited, implying survival rather than re-colonization.

We found diverse epiphytic lichen communities, similar to areas not impacted by the eruption (Redón 1974, Rubio et al. 2013), had survived in close proximity ( $c a .20-50 \mathrm{~km}$ ) to the vent of the 2011 Puyehue-Cordón Caulle eruption, despite up to $50 \mathrm{~cm}$ of tephra deposition (figure 1, tables
1 and 2). We found 81 lichens species compared to 141 (Rédon 1974) and 183 species (Rubio 2013) found in floristic surveys of nearby Vicente Pérez Rosales and Conguillío National Parks, respectively. Our study encountered a large portion of this regional lichen flora considering we only sampled seven plots, further implying no large lichen die off occurred in the six months after the eruption. The lichens that survived represented a wide range of morphological, chemical and reproductive traits, implying 
no one group of lichens was differentially exterminated (table 1). In contrast to Ksudach, we observed very few ground-dwelling lichens at Puyehue-Cordón Caulle. Since we conducted fieldwork so soon after the Puyehue-Cordón Caulle eruption, it is unclear when or whether the ground dwelling lichens will colonize the tephra. Many ground or rock-dwelling species found in the area were not present in our sample (Redón 1974), leaving open the possibility that those species were buried in the eruption and therefore undetected in our sampling. It remains possible that the deeper tephra areas will have suppressed vascular vegetation for some time, potentially allowing lichens to colonize and persist. This could produce a similar positive association of lichen species richness and tephra depth, as was found at Ksudach. However, since lichens were not frequent on the ground prior to the eruption, we expected most of the lichen diversity and abundance to remain in the canopy. Similar to Mount St. Helens where lichens occurred in relict forest patches that experienced only tephra fall, we observed lichen persistence across tephra depths at Puyehue-Cordón Caulle. The mechanisms permitting lichen persistence after the Puyehue-Cordón Caulle eruption remain unclear. However tephra texture, temperature and chemistry likely play important roles as does tree architecture, which could provide shelter from the brunt of the tephra fall. If the characteristics of the eruption were different, such as laterally projected tephra, more dense lithic ejecta, more fine ash, all of which occurred at Volcán Chaitén south of Puyehue-Cordón Caulle (Swanson et al. 2016), then we expected lichens would experience more mortality. Indeed, preliminary results from a parallel study conducted by the authors four years after the 2008 eruption of Volcán Chaitén suggest very different lichen responses from those at Puyehue-Cordón Caulle.

The vertical orientation of tree boles and the assumed vertical descent of the tephra likely protected the lichens from much of the physical impact force and abrasion of the falling tephra. Also, most of the tephra from this eruption was pumice, which has very low density. The impact force of pumice against the tree boles was likely tolerable for the lichens. Another factor potentially contributing to lichen's persistence was widespread tree survival, which left their bark intact. Dead trees apparently killed by the tephra deposition had not yet lost their bark, consequently lichen cover at the plot and tree levels may change in the next 5-10 years as bark of dead trees falls off or if trees thought to be dead turn out to have had delayed re-sprouting.

We also note the persistence of lichens as indication there was likely limited to no volcanic fluorine emissions sufficient to produce lichen damage. Many lichens are sensitive to acidic compounds such as the hydrogen fluoride (HFl) (Nash 1971), the form of fluorine frequently emitted from explosive volcanic events. If there were significant HFl emissions from the 2011 Puyehue-Cordón Caulle eruption, we believe we would not have observed the diversity and abundance of lichens both on the plots.

\section{CONCLUSIONS}

Epiphytic lichens near volcanic eruptions can apparently survive up to $50 \mathrm{~cm}$ of tephra deposition at least three years after an eruption. We attribute the persistence of epiphytic lichens to the vertical orientation of the trees upon which they grow, the low-density, pumice-rich tephra of the 2011 Puyehue-Cordón Caulle eruption and the apparent lack or limited extent of gaseous emissions toxic to lichens. It is notable that lichens, thought being some of the most sensitive organisms to atmospheric conditions, survived a substantial volcanic eruption in close proximity to the vent of the Puyehue-Cordón Caulle eruption.

Lichen responses to the Puyehue-Cordón Caulle eruption may have differed from impacts of other forest disturbances, such as logging or fire, since the forest was largely left intact, with mostly branch damage or tree mortality confined to deeper tephra deposition and no tree removal. Also, gaseous volcanic emissions that could produce lichen necrosis or mortality (eg. sulphur, fluorine or chlorine compounds) may have differed from chemically similar anthropogenic air pollution sources, as volcanic eruptions may be of shorter duration and lower concentration than are chronic emissions from industry. These differences between volcanic and other disturbances belie the need for conceptual framework within which to compare lichen responses to different disturbance processes.

\section{ACKNOWLEDGEMENTS}

The fieldwork for this study was supported by grants from the US National Science Foundation (NSF 0917697 and 0823380 ) to J. Jones. We are thankful to F. Swanson and J. Jones for many useful comments on earlier drafts and for helping rephoto the tree quadrats. Thanks also to Alicia Marticorena at the herbarium of Universidad de Concepción (CONC) for mailing the lichens collected during this study. We acknowledge the help of CONAF for granting research permits. Thanks also to Cabañas Anticura for excellent accommodations during our fieldwork. Finally, we would like to thank the Chilean border authorities for facilitating working in the area between the Chilean and Argentinean border stations.

\section{REFERENCES}

Antos JA, DB Zobel. 2005. Plant responses in forests of the tephra-fall zone. In Dale VH, FJ Swanson, CM Crisafulli eds. Ecological responses to the 1980 eruption of Mount St. Helens. New York, USA. Springer. p. 47-58.

Bjarnason ÁH. 1991. Vegetation on lava fields in the Hekla area, Iceland. Uppsala, Sweden. Acta Phytogeographica Suecica 77. $110 \mathrm{p}$.

Conti ME, G Cecchetti. 2001. Biological monitoring: lichens as bioindicators of air pollution assessment - a review. Environmental Pollution 114(3): 471-492.

Davies FB, G Notcutt. 1988. Accumulation of fluoride by lichens 
in the vicinity of Etna volcano. Water, Air \& Soil Pollution 42(3): 365-371.

Galloway DJ. 1988. Plate tectonics and the distribution of cool temperate Southern Hemisphere macrolichens. Botanical Journal of the Linnean Society 96(1): 45-55.

Galloway DJ. 1992. Lichens of Laguna San Rafael, Parque Nacional Laguna San Rafael, Southern Chile: indicators of environmental change. Global Ecology and Biogeography Letters 2(2): 37-45.

Galloway DJ. 1995. Lichens in Southern Hemisphere temperate rainforests and their role in maintenance of biodiversity. In Allsopp D, RRColwell, DL Hawksworth eds. Microbial diversity and ecosystem function. Wallingford, UK.CAB International.p.125-135.

Grime J. 1977. Evidence for the existence of three primary strategies in plants and its relevance to ecological and evolutionary theory. American Naturalist 1977: 1169-1194.

Grishin SY, R Moral, PV Krestov, VP Verkholat. 1996. Succession following the catastrophic eruption of Ksudach volcano (Kamchatka, 1907). Plant Ecology 127(2): 129-153.

Hawksworth DL, F Rose. 1970. Qualitative scale for estimating sulphur dioxide air pollution in England and Wales using epiphytic lichens. Nature 227(5254): 145-148.

Jackson,TA. 1971. A study of the ecology of pioneer lichens, mosses, and algae on recent Hawaiian lava flows. Pacific Science 1: 22-32.

Jackson TA, WD Keller. 1970. A comparative study of the role of lichens and inorganic processes in the chemical weathering of recent Hawaiian lava flows. American Journal of Science 269(5): 446-466.

Johansson P. 2008. Consequences of disturbance on epiphytic lichens in boreal and near boreal forests. Biological Con- servation 141(8): 1933-1944.

Kitayama K, D Mueller-Dombois, PM Vitousek. 1995. Primary succession of Hawaiian montane rain forest on a chronosequence of eight lava flows. Journal of Vegetation Science 6(2): 211-222.

Kurina LM, PM Vitousek. 1999. Controls over the accumulation and decline of a nitrogen-fixing lichen, Stereocaulon vulcani, on young Hawaiian lava flows. Journal of Ecology 87(5): 784-799.

Nelson PR, B McCune, T Wheeler, L Geiser, CH Crisafulli. (in press). Lichen community development along a disturbance gradient at Mount St. Helens. In Dale VH, CH Crisafulli eds. Ecological Responses Revisited 35 years after the 1980 Eruptions of Mount St. Helens. NY, USA. Springer-Verlag.

Nash TH. 1971. Lichen sensitivity to hydrogen fluoride. Bulletin of the Torrey Botanical Club 98(2): 103-106.

Redon J. 1974. Observaciones sistemáticas y ecológicas en líquenes del Parque Nacional Vicente Pérez Rosales. Anales del Museo de Historia Natural de Valparaíso 7: 169-222.

Rubio C, M Saavedra, M Cuellar, R Diaz, W Quilhot. 2013. Epiphytic lichens of Conguillío National Park, southern Chile. Gayana Botanica 70(1): 66-81.

Sipman HJM, T Raus. 1995. Lichen observations from Santorini (Greece). Bibliotheca Lichenologica 57: 409-428.

Skottsberg C. 1941. Plant succession on recent lava flows in the island of Hawaii. Goteborgs Kungliga Vetenskaps och Vitterhets-Samhället Handlingar, Sjatte Foljden, Series B1: $8.32 \mathrm{p}$.

Swanson FJ, J Jones, C Crisafulli, ME González, A Lara. 2016. Puyehue-Cordón Caulle eruption of 2011: tephra fall and initial forest responses in the Chilean Andes. Bosque 37(1): 85-96. 
